\title{
A Good Cop is Never Cold or Hungry: Antecedents and Consequences of Financial Literacy among Members of the Royal Malaysia Police
}

\author{
Hafizah Mat Nawi ${ }^{1}$, Hafez Shahril Hussin ${ }^{2}$ \\ ${ }^{1}$ Faculty of Defence Studies and Management, Department of Defence Human Resource Management, National \\ Defence University of Malaysia, Malaysia. \\ ${ }^{1}$ E-mail: hafizah.matnawi@upnm.edu.my (Corresponding author) \\ ${ }^{2}$ Independent Researcher, Kuala Lumpur, Malaysia.
}

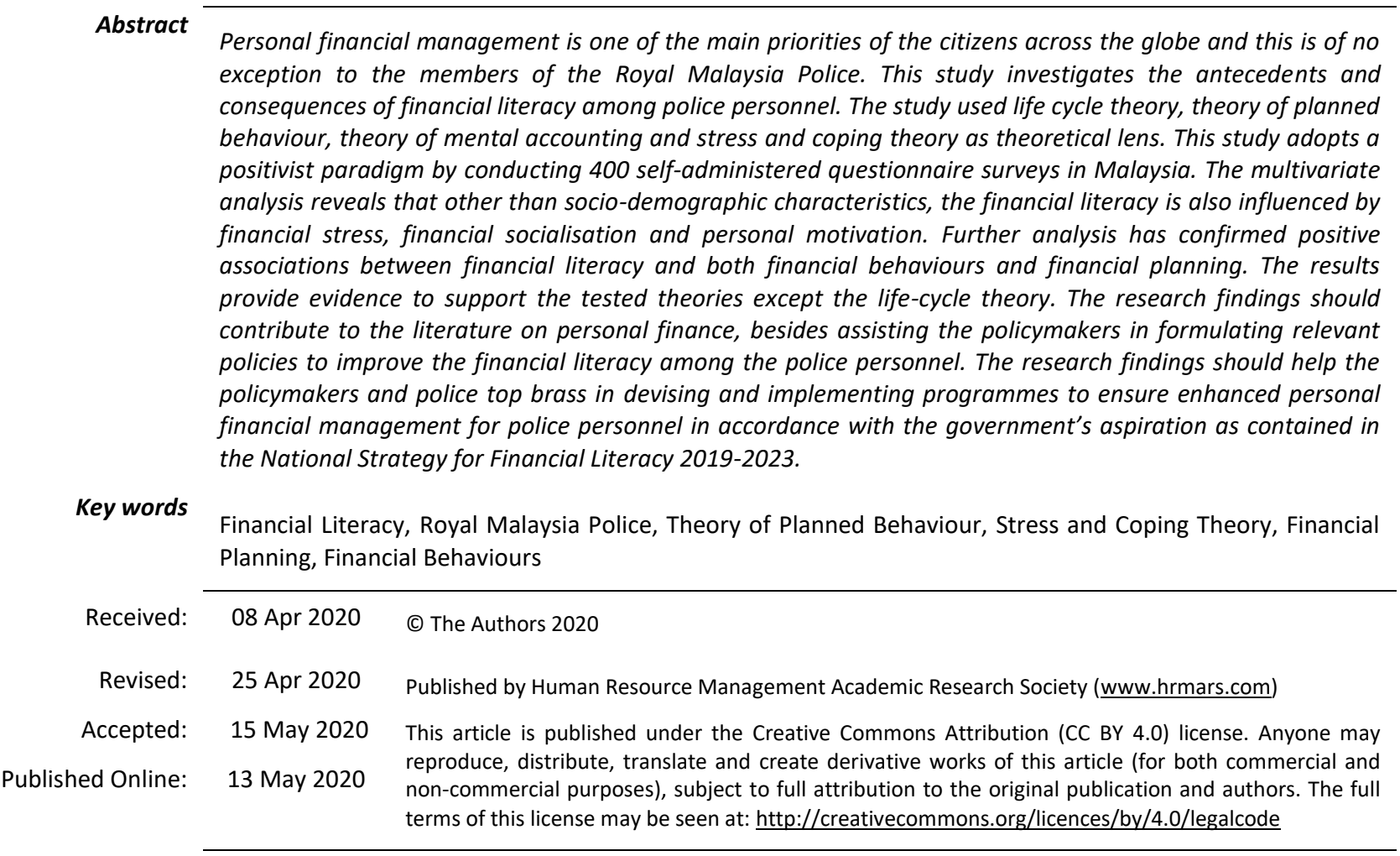

\section{Introduction}

The financial literacy denotes the relevant knowledge and skills to deal with daily financial problems and decisions in one's life. It refers to a person's ability to comprehend, evaluate, coordinate and communicate matters relating to personal finance (Vitt et al., 2000). An improved level of financial literacy contributes towards achieving better financial planning necessary for solid financial security. In turn, financial security leads to a person's well-being since he or she is capable of making sound financial decisions which are specifically tailored to suit his or her financial needs and preferences. Additionally, financially literate individuals would less likely to be over-indebted (Lusardi \& Tufano, 2015). They will plan for their personal financing including their retirement planning (Van Rooij et al., 2012) by actively participating in the financial markets with improved and diversified portfolios (Von Gaudecker, 2015).

Despite the significant role of the financial literacy in a person's daily life, extant findings still indicate that the population of financially illiterate individuals around the world is still high (Brown \& Graf, 2013; 
Thaler, 2013; Lusardi \& Mitchell, 2014). Low financial literacy is widespread in developed and developing countries (Lusardi \& Mitchell, 2011). Klapper et al. (2015) who conducted a global financial literacy survey found that two-thirds of the adults worldwide are financially illiterate. Inadequate knowledge of financial literacy, mismanagement of finance and stressing over personal finance affect the quality of financial decision making and financial well-being (Arpana, 2020; Delafrooz et al., 2010). Having a financial problem affects the individuals' daily life, which in turn lowers their job productivity (Delafrooz et al., 2010) and health (O'Neill et al., 2006). Thaler (2013) emphasised that the problem requires effective measures and viable solutions to remedy it.

The general public should be properly educated on the significance of financial literacy and good management of finance to guarantee their financial well-being and improved quality of living. On the other hand, Calcagno \& Monticone (2015) argued that a lower level of financial literacy does not mean that families are obliged to produce bad financial decisions. They can substitute their financial illiteracy with an expert's advice (Calcagno \& Monticone, 2015). However, the expert's advice might become a disadvantage to the households in case of biased advice (Stoughton et al., 2011).

Although Malaysia has successfully managed much of its financial troubles, it is evident that the country is still beleaguered with the problems of households' financial steadiness. According to the Malaysia Bankruptcy Statistics Report (2018), there are 303, 415 bankruptcy cases where more than fourfifths of the cases involve those from age 25 to 54 . In fact, the personal finance environment in Malaysia is similar to those countries facing financial transitions like Korea, and India (Mahdzan et al., 2019; Mahapatra et al., 2019; Sohn et al., 2012).

To that extent, financial literacy is equally useful for police personnel in making sound short- and long-term financial decisions. Very limited researches studied financial-related issues among the police personnel. Low level of financial literacy among the police personnel leads to financial mismanagement and financial mishap which could entice them to engage in corruption and misuse of power. This will eventually affect the national security as it might jeopardise the effectiveness, integrity, and impartiality of the police institution as the main law-enforcement agency which is responsible to maintain law and order. Besides, the study is significant as the overall strength of the police force is estimated at more than $10 \%$ of the civil servants in Malaysia (The Official Portal of Royal Malaysia Police). This study, therefore, attempts to examine the determinants of financial literacy and the extent of personal financial mismanagement among members of the Royal Malaysia Police (RMP) and the impacts thereof.

The remainder of this study is arranged according to the following structure. The further section shows discussions on the extant literature. It outlines the financial literacy, its influencing factors and consequences. This is followed by the research methodology, findings and implications of the study. The final section draws conclusions on the contributions and limitations of the study, apart from suggesting recommendations for further research in the future.

\section{Literature review and hypotheses development}

The literature mainly focuses on financial literacy, its determinants and impacts on financial planning, financial behaviour, and financial well-being.

\subsection{Theories}

The study used the life cycle theory, theory of mental accounting, theory of planned behaviour and stress-and-coping theory as theoretical lens.

\subsubsection{Life-cycle Theory}

Life-cycle theory initially proposed by Penrose (1952, as cited in Mat Nawi, 2015) focuses on the development of an individual's consumption and savings behaviours. The theory assists in understanding the way people utilise and save according to their level of income, retirement objectives, life expectancy and inter-generational transfer motives (Chaffin, 2013). The theory predicts that consumption and savings behaviours change significantly with the objective (i.e. income, rates of returns, wealth) and subjective factors (i.e. age, marital status, socio-economic and demographic conditions) during the various stages of 
an individual's life. The individuals should fully prepare sufficient resources while they are on their active employment for future use, particularly after they retire and become financially less active.

\subsubsection{Theory of mental accounting}

The theory of mental accounting involves an individual's behaviours in planning for expenditure and future savings. This theory was developed by Thaler (1985) who defined it as "the set of cognitive operations used by individuals and households to organise, evaluate, and keep track of financial activities" (Thaler, 1999, p.183). Persons continually encode and classify their expenditure to evenly distribute the money according to needs and preferences, monitor the expenditure and evade excessive spending on trivial products (Cheema \& Soman, 2006; Thaler, 1999). Most people would keep mental accounts, especially those who manage monthly expenditure. Zhang \& Sussman (2017) argued that mental accounting serves as a guide for individuals to keep track of their financial activities and control their consumption. Individuals who can effectively manage their expenditure tend to save more (Kast et al., 2016). Mental accounting can be enhanced by peer pressure, usually involving the action of notifying a family member or friend to observe the spending plan carefully to avoid extravagant spending, thus increasing the cost of transferring money from one spending category to another (Iregui-Bohórquez et al., 2018; Kast et al., 2016).

\subsubsection{Theory of planned behaviour}

The theory of planned behaviour (TPB) initially developed by Fishbein \& Ajzen (1975) emphasises the individuals' behaviour arising from their intentions to behave - they act according to what they believe is the most appropriate. According to Ajzen \& Fishbein (2005), there are three factors that determine human actions, namely behavioural belief, normative belief, and control belief. The TPB's role is to guide the evaluation of factors that may contribute to financial behaviours related to the maintenance of an emergency fund and spending in excess of income. The theory states that the background factors influence beliefs which influence attitudes and perceived behavioural control, that in turn influence intent, and ultimately determine behaviour (Ajzen \& Fishbein, 2005).

\subsubsection{Stress and Coping Theory}

Lazarus \& Folkman's (1984) theory of stress and coping provides the conceptual framework for this study. A brief explanation of the theory and a definition of some of its key terms such as psychological stress, cognitive appraisal, and coping are included to promote understanding of its present application. Psychological stress is conceptualised as "a particular relationship between the person and the environment that is appraised by the person as taxing or exceeding his or her resources and endangering his or her well-being" (Lazarus \& Folkman, 1984, p.19). According to the theory, the process of cognitive appraisal is a mediator of transactions between a person, the environment and the immediate and longrange outcomes of the transactions. Cognitive appraisal denotes the process in which an individual evaluates the relevancy of a specific interaction with the environment which may affect the overall wellbeing. On the other hand, coping is viewed as a process based on the context of a particular situation that is cognitively appraised as significant. For instance, consider police personnel encounters a situation requiring potential financial expenditure and he is appraising the effects the expenditure might have on personal well-being, both immediately and for the longer-term.

\subsection{Conceptualisation of Financial Literacy}

The financial literacy relates to a person's knowledge about concepts, principles and technological apparatuses which are related to finance or money. Some researchers define it based on skills and some define it based on financial knowledge. The earliest definition by Noctor et al. $(1992$, p.4) defined it as "the ability to make informed judgments and take effective decisions regarding the use and management of money". Noctor et al. (1992) basically attempted to relate financial literacy to skills.

On the other hand, Commonwealth Bank Foundation (CBF) (2004) relates financial literacy to financial knowledge, describes financial literacy as "the ability to balance a bank account, prepare budgets, save for the future and learn strategies to manage or avoid debt" (p.1). Alternatively, the Organisation for Economic 
Co-operation and Development (2013) delineated the financial literacy as a mix of knowledge, consciousness, talent, attitude, and conduct which are essential to produce perfect financial decisions necessary for personal financial happiness and security. On the other vein, Lusardi and Mitchell (2014) in their study defined the financial literacy as "people's ability to process economic information and make informed decisions about financial planning, wealth accumulation, pensions, and debt" (p.2).

Despite a number of definitions of financial literacy, the most difficult issue in this research is on the measurement of financial literacy. Allgood \& Walstad (2016) argued that studies on financial literacy mostly concentrate on "the cognitive dimensions of the construct and relies on a test measure of what people know or understand about financial concepts" (p.2). This objective method in gauging financial literacy is mostly applied by the economists and others by employing a set of true-false or multiple-choice test questions which are included in a questionnaire (e.g. Thapa, 2015; Lusardi \& Mitchell, 2011; Calamato, 2010).

Regardless, financial literacy can be measured in different ways. Dam \& Hotwani (2018) classified financial literacy variables into basic and advanced based on an extensive review of the literature. Basic variables of financial literacy include compound interest rate, inflation, risk, fixed deposit, tax filing and time value of money. Conversely, variables for advanced financial literacy include stocks, mutual funds, diversification, superannuation and insurance. Most of the studies use a combination of basic and advanced variables in measuring financial literacy. For example, Boon et al. (2011) measured the financial literacy using inflation rate, risk level, stock market, knowledge of mutual funds, risk diversifications and knowledge related to insurance, tax filing and time value of money. Alternatively, works of Lusardi \& Mitchell (2007) touched upon the role of stock market, fluctuation in the asset, knowledge of mutual funds, the relationship between interest rates and bond prices, risk and risk diversifications, and long-term return. Similarly, Fernandes et al. (2014) also measured the financial literacy using a combination of basic and advanced variables which are related to compound interest rate, inflation rate, risk level, knowledge of mutual funds, a function of the stock market, and risk diversifications.

Another issue is the type of questions. Even though the economists preferred to measure financial literacy by providing an objective assessment like multiple-choice questions, there are some researchers who preferred to measure the financial literacy through subjective assessment (e.g. Stanca, 2012). Van Rooij et al. (2011) gauged the financial literacy by using two types of objective questions i.e. basic and advanced literacy. The questions cover topics related to numeracy, time value of money, inflation, interest compounding, and money illusion. In addition, a study by OECD International Network on Financial Education (OECD, 2013) concluded that persons can achieve, improve or maintain their financial well-being through the right application of the financial literacy. It includes knowledge, awareness, and understanding of financial situations; skills and behaviours towards achieving financial well-being; and motivation, confidence, and attitudes whether internally or psychologically. The next literature discusses the contributing factors to financial literacy, followed by the effects of those factors on a person's financial behaviours and planning to accomplish financial well-being.

\subsection{Contributing factors to financial literacy}

This section presents the literature of antecedents of financial literacy. The factors had been identified through past literature. This study found a total of eight contributing factors, namely, age, marital status, age, human capital, income level, motivation, financial socialisation, and financial stress.

\subsubsection{Gender}

Gender refers to the sex of human beings; which is female and male. The literature confirms that gender differences influenced persons' financial literacy. The latest study of Kalmi \& Ruuskanen (2018) confirmed that financial literacy is lower among women. Studies found that men have a higher level of financial knowledge as compared to women (Almenberg \& Dreber, 2015; Falahati \& Sabri, 2015; Mottola, 2013; Fonseca et al., 2012; Van Rooij et al., 2011; Chen \& Volpe, 2002). Similar findings have been found by Bottazzi \& Lusardi (2016) who conducted a study on financial literacy in 140 countries of both developed and developing nations. Most men received adequate financial knowledge before pursuing their tertiary education. Furnham et al. (2015) asserted that most females have the assumption that they will have 
someone in the future to manage their finance. Evidence of this can be seen in America where men usually make financial decisions (Bongini et al., 2015).

Likewise, Fonseca et al. (2012) who studied the role of the gender gap in the financial literacy found men are more informed in terms of financial aspects as compared to women since they made a financial decision within families. Thus, men will develop their financial knowledge from time to time as compared to women who are in charge of household functions and nurturing roles (Bongini et al., 2015). The finding is in line with the results found by Van Rooij et al. (2011) who affirmed that individuals who possess adequate financial knowledge are capable of managing their assets in a proper portfolio.

In addition, Wong et al. (2013) examined the tendency of gambling behaviour between these two genders and proved men possess a relatively higher level of risk-taking attitude as compared to women, in which $14 \%$ of men used to gamble at a problematic level while women are only at $3 \%$. Furnham et al. (2015) confirmed that women are more likely to view money as security and love because their gender characteristic is more vulnerable and needy. Conversely, men view money as freedom and power (Calamato, 2010) as they are more competitive (Furnham et al., 2015).

Despite the inverse association between women and financial literacy, Wagland \& Taylor's (2009) research on the financial literacy involving the undergraduate business students in Australia found contradictory results. They found that female students had answered correctly many times as compared to male students except the questions on estate planning and financial goals.

The above discussion leads to the first hypothesis:

H1.1: Male is positively associated with financial literacy.

\subsubsection{Marital status}

Previous empirical studies provide evidence on an association between marital status and the levels of financial literacy (Brown and Graf, 2013; Van Rooij et al., 2011; Calamato, 2010). According to Calamato (2010), persons who possess inadequate knowledge on financial literacy are prone to experience more risks in financial decisions. This may result in debt and imperil the well-being of their relationship with others. In parallel with such evidence, Brown \& Graf (2013) found that non-married individuals have a relatively low level of financial literacy as opposed to married persons. In contrast, married persons tend to have a high level of financial literacy since the debt problem is a major threat to marital happiness (Dew, 2016).

Furthermore, there is a significant difference between couples with children and couples without children. Pahl (2005) asserted that couples without children tend to practise more independent money management. Alternatively, couples with children prefer to practise joint pooling system as they are more concerned with the budget. Couples with children tend to have a collective financial arrangement (Lauer \& Yodanis, 2014). This indirectly differentiates between the levels of financial literacy among these two groups. However, an empirical study by Servon \& Kaestner (2008) found no significant differences between couples with children and couples without children in terms of financial literacy levels. A similar concern is also applicable for those with dependent family members as Mottola (2013) has found that families hosting such individuals have low levels of financial literacy.

Accordingly, the researcher proposes the following hypothesis:

H1.2: Married status is positively associated with financial literacy.

\subsubsection{Age}

Age is another factor correlated with the level of financial literacy, with previous research works suggesting lower levels among younger and older individuals and higher levels among adults currently in the middle of their life cycle (Agarwal et al., 2009; Hogarth \& Hilgert, 2002). In particular, the study by Van Rooij et al. (2007) has shown that advanced financial literacy is low among young respondents, while middle-aged respondents (aged between 40 and 60 years) score higher levels. Furthermore, their outcomes show a decreasing level of advanced financial literacy as the respondents become older (61 years old and above). Similarly, Lusardi \& Mitchell (2011) have shown that respondents younger than 25 or older than 65 years old tend to answer less correct questions than those aged between 25 and 65 .

Interestingly, De Clercq \& Venter (2009) have reported that an individual's financial literacy follows a life-cycle theory: the level of financial literacy increases as the age increases, but the positive association 
will cease when it reaches the age of 40 years. Accordingly, most of the older respondents are unable to answer questions related to interest rates and general financial knowledge, whereas their younger counterparts have a higher likelihood of limited access to finance and limited experience in relation to financial products and services (Struwig et al., 2016). In contrast, an empirical study by Chen \& Volpe (2002) has presented slightly different findings from De Clercq \& Venter (2009). The study has specifically revealed that respondents who are 40 years old and older are less likely to be financially knowledgeable than those who are 30 years old and younger. Meanwhile, Rootman \& Antoni (2018) have found no significant relationships between age and financial literacy altogether.

Based on the presented evidence, the hypothesis is proposed as follows:

H1.3: There is a positive association between person's age and financial literacy.

\subsubsection{Human capital}

Human capital can be defined as a mix of knowledge and skills that individuals possess (Mat Nawi, 2015), which can be acquired whether through formal or informal education. Lee \& Lown (2012) asserted that individuals who possess financial education had higher positive savings scores as compared to those without financial education. They added persons who obtained financial education in primary schools had a higher level of savings attitude as compared to those who received financial education while studying in college.

Struwig et al. (2016) asserted the existence of a relationship between financial literacy and the level of education. Financial literacy is found lower among less-educated people and higher among educated individuals who attended college or graduated from high school (Kalmi \& Ruuskanen, 2018). In addition, education background related specifically to 'finance' may differentiate the level of financial literacy as well. Nano \& Cani's (2013) research on students studying at universities affirmed that the majority of them have inadequate knowledge on financial literacy as they did not receive any personal financial education, while students who have undergone any form of money management course are more literate. A high level of formal education could increase the level of financial literacy (Peng et al., 2007) as people tend to be more responsible in their financial behaviours (Bernheim et al., 2001). The significance of proper financial literacy education demands the role and service of many financial aid professionals all over the world.

On the other hand, informal education related to finance may affect the levels of financial literacy. A study on workplace financial education and workplace satisfaction by Hira \& Loibl (2005) has revealed that those who undergo employer-sponsored workshops relating to financial education or awareness tend to produce better decisions on finance or investment confidently, besides being capable of managing their credit use (Garman et al., 1999). Furthermore, a study by Wagner (2015) showed that education on finance has a positive association with an individual's score of financial literacy. His study used data from the National Financial Capability Study (NFCS) in 2012 to assess the effects of financial education on an individual's score of financial literacy, as well as his financial behaviours in short- and long-terms.

Conversely, studies on the effects of retirement workshops showed varied results. According to Bayer et al. (1996), such employer-organised workshops had improved the employees' contributions and involvement in voluntary savings plans. As stated by Duflo \& Saez (2003), such workshops had positively improved the involvement in the savings plan, but not in contributions. Alternatively, a study by Lusardi \& Mitchell (2007) affirmed the positive effect of retirement seminars, but only for individuals with fewer assets or educational background.

In terms of credit counseling, Elliehausen et al. (2003) stated that the counseling has improved the creditworthiness and borrowing behaviour of individuals. Similarly, Hirad \& Zorn (2001) reported that credit counseling programmes for prospective house owners had reduced the rate of delinquency. Interestingly, Yoshino et al. (2015) who conducted a study on financial education in Asia affirmed that financial education provision remains under the academic and policy radar in Asia. They stressed that there are little discussions on policies related to financial education and scarcity of economic research on the topic.

The aforementioned discussion recommends the hypothesis as follows:

H1.4: There is a positive association between human capital and financial literacy. 


\subsubsection{Income level}

Income or wealth is the resources of the households for their consumptions. According to Brian (2015), a household's income can be defined as money within the house from economic activities. Income can be obtained from employment or received from other sources such as rental or interest, business, and benefits from states. Previous studies found a relationship between income and financial literacy. Financial literacy is found lower among low-income earners and vice versa (Kalmi \& Ruuskanen, 2018; Struwig et al., 2016; De Clercq \& Venter, 2009). In addition, Rootman \& Antoni (2018) found a statistically significant relationship between financial literacy and income level. Their study showed that black consumers who earn high-income level scored a higher mean score for financial literacy than black consumers that earn at lower income levels.

Meanwhile, Monticone (2010) argued that assets have a minor effect, but a positive relationship with financial literacy. Similarly, Hastings \& Mitchell (2011) proved through experiments that assets have a relationship with financial literacy. Atkinson and Messy (2012) also gave evidence on a parallel association between income levels and the levels of financial literacy. In addition, individuals with low earnings are normally school-dropouts who are financially illiterate, whereby high-income earners have the ability to successfully manage their financial aspects due to good financial attitudes and behaviours (Calamato, 2010). In a reverse situation, persons with a high level of financial literacy have the ability to produce better decisions financially and generate more income or assets compared to persons with a low level of financial literacy.

In light of the above evidence, the hypothesis is proposed as follows:

H1.5: There is a positive association between income level and financial literacy.

\subsubsection{Financial socialisation}

Financial socialisation refers to a situation in which a person attains knowledge as well as skills and attitudes from his surroundings (Sohn et al., 2012). The socialisation process can be viewed as an "assimilation of the internalised and collective forms of values and norms" (Schuchardt et al., 2009, p.86). In general, individuals acquire knowledge to maximise their consumer's role in the financial market. Financial socialisation agents comprise of family members, peers at school or workplace, media and culture (Kim \& Chatterjee, 2013). According to Chen and Volpe (2002), the individuals' financial literacy may be influenced by their employers and people in the community.

Remarkably, each agent works differently throughout the life-cycle. Sohn et al. (2012) affirmed that parental influence would change negatively over a long period; whereas peer influence would grow stronger. This is supported by Bachmann et al. (1993) who contended that peer influence on financial decisions developed gradually in children since their primary school years. Each person interacts and will be exposed to numerous socialisation agents while he or she grows older.

Moreover, previous studies have also shown the influence of media on the individuals' financial literacy (Sohn et al., 2012). Kim \& Chatterjee (2013) found a positive relationship between the extent people resort to media in search for financial information and practices. A similar finding was found by Schor (2004) who studied the relationship between advertisements on the television and kids' buying demands and materialism.

In addition, individuals with high levels of financial literacy prefer to obtain information from the internet, financial magazines and also newspapers (Van Rooij et al., 2011; Rootman \& Antoni, 2018). Van Rooij et al. (2011) added that the respondents prefer to depend on formal financial advice such as personal financial planners or advisers which normally happened among wealthy individuals.

The above discussions lead to the following hypothesis:

H1.6: Financial socialisation is positively associated with financial literacy.

\subsubsection{Financial Stress}

The use of Lazarus \& Folkman's (1984) framework has not been commonly applied to financial stress studies. An exception is a study by McPherson (2012) which claimed to be the first to examine the effectiveness of various coping styles on financial stress among college students. Findings found that the perception of control is significantly related to the choice of problem-focused strategies in instances of 
financial stress. Respondents who relied heavily on emotion-focused strategies reported more depressive and anxiety symptoms than those with lower dependence on such approaches. Remarkably, these relationships did not apply to life stress which maintains the practice of studying financial stress separately from life stress in a broader context due to possible qualitative differences between them.

Following this, other studies of financial stress have commonly used subjective perceptions of stress instead of objective measures (Smith \& Weatherburn, 2013; O'Neill et al., 2006). Studies that relied on objective measures of financial stress typically do so by using measurements that constitute negative financial events, such as taking qualifying hardship distributions from retirement plans (Marks, 2007).

Previous literature had also presented the influence of financial behaviour on financial stress, such as a study by O'Neill et al. (2005) on the credit counselling programme which found that participants with higher scores of self-evaluation and a positive financial behaviour were more likely to have lower levels of financial stress. Good savings habit and a proper way of managing money can reduce financial stress (Bongini \& Zia, 2018).

In addition, Bernardo \& Fernando-Resurreccion (2018) who studied the impacts of financial stress on the financial well-being of Filipino students showed that persons who experienced low financial stress are more likely to achieve life satisfaction and vice versa. Kindle (2010) also proved a similar association who found a relationship between financial stress and poverty.

Based on the above evidence, the hypothesis is proposed as follows:

H1.7: Financial stress is positively associated with financial literacy.

\subsubsection{Motivation}

The motivational influence on human behaviour is explained by the force model and utility model of Vroom (1964) and Samuelson (1967), respectively. The theories focus on the role of expectancy, instrumentality, and valence or utility. Persons are motivated by matters or things of good results. In tandem with such evidence, Mandell \& Klein (2007) discovered a positive association between motivation and financial literacy. Similar association has been proved by Locke and Latham (2004) who stated that individuals possess high levels of financial literacy if they are highly motivated by perceptions and awareness concerning financial stability in their life.

In parallel with the above explanations, previous researches like Clarke et al. (2005) affirmed the role of parents to greatly motivate and influence consumer behaviours of their offspring who knew more on how to manage assets or money from their fathers and mothers. Motivation by parents will have a pivotal role in improving their kids' literacy. So as to relate the motivation of parents to sons and daughters, parents normally have higher hopes and expectations relating to job and savings for the sons; while their daughters are taught and motivated to rely on them financially, especially during university days (Edwards et al., 2007). Edwards et al. (2007) argued that such a difference between men and women can be attributed to their belief as men are inclined to view money as a power to make them more socially appealing; while women normally have a submissive belief in money (Calamato, 2010).

Accordingly, the hypothesis is as follows:

H1.8: Motivation is positively associated with financial literacy.

\subsection{Consequences of Financial Literacy}

This section presents the literature on the consequences of financial literacy. The following literatures discuss the impacts of financial literacy on three variables, namely financial behaviour, financial planning and financial well-being. Further discussions cover the mediating effect of financial behaviour and financial planning on the association between financial literacy and financial well-being.

\subsubsection{Financial planning- Mediator}

Financial planning can become a guide for individuals to plan their financial decisions, which includes benefits and consequences of the decisions (Malaysia Financial Planning Council-MFPC, 2004). Boon et al. (2011) affirmed that persons who are financially literate prefer to plan their finance. Similarly, Xiao \& Porto (2016) asserted that those who possess a high level of financial literacy tend to plan their spending, keep the budget and try to reduce borrowings. 
Furthermore, persons with a high level of financial literacy are generally good at making financial plans, whether current or retirement plans (Lusardi \& Mitchell, 2011) and thus, they are able to produce sound financial decisions. The MFPC (2004) stressed that in order to manage financial needs efficiently and effectively, the individuals should utilise their savings to accumulate wealth, then preserve and distribute wealth. Financial needs could be related to estate planning, tax planning, investment, risk management, cash and credit management and retirement plan.

Additionally, Boon et al. (2011) who conducted a study on financial literacy and financial planning confirmed a positive association between these variables. Persons who possess higher levels of financial literacy are inclined towards planning for their finance quite frequently, as compared to those with medium and low levels of financial literacy (Boon et al., 2011; Lusardi \& Mitchell, 2007). Lack of financial knowledge or information is identified mostly in individuals who did not plan for their personal finance (MFPC, 2004).

Related to financial well-being, Cheah et al. (1998) argued that a wise and strategic financial planning could certainly lead to ultimate financial freedom. This sense of security will indirectly satisfy a person's financial well-being as confirmed by a recent study by Adam et al. (2017). Remarkably, they also found a mediating effect of financial planning and financial behaviour on the association between financial literacy and financial well-being.

Based on these pieces of evidence, the study suggests the following hypotheses:

H2: There is a positive association between financial literacy and financial planning.

H4: There is a positive association between financial planning and financial well-being.

H6: Financial planning mediates the association between financial literacy and financial well-being.

\subsubsection{Financial Behaviour- Mediator}

Financial behaviour denotes financial decisions and actions, for example, behaviours related to finance which may affect a person's financial well-being and state of conditions like procrastination to pay utility bills, failure or inaction in planning for future expenditures and lack of proper research before buying any financial products. Financial behaviour varies from the financial knowledge and it is significant to know how the latter might affect the former.

Previous studies showed an association between financial literacy and financial behaviour. Financial behaviours can be referred to as behaviours related to planning, budgeting, managing and controlling the finance (Herawati et al., 2018). For instance, behaviours related to savings, investing, using or spending money, and evaluating financial activities. Since good financial behaviours are discussed closely with a sound financial planning, both variables will indirectly reduce financial stress, resulting in individuals' financial well-being (Xiao et al., 2006).

Financial literacy can be the main predictor in forming financial behaviours. It can positively direct financial behaviour and help strengthen one's financial status (Zulaihati \& Susanti, 2020; Xue et al., 2018; Cheah et al., 2015; Lusardi \& Tufano, 2015; Lusardi \& Mitchell, 2014; Klapper et al., 2013). Financially literate individuals tend to have a better understanding of the financial products and markets. They are more likely to accumulate wealth (Jappelli et al., 2019; Mottola, 2013; Van Rooij et al., 2012), have a good savings behaviour (Butt et al., 2017) and effective financial planning (Lusardi \& Tufano, 2015; Lusardi \& Mitchell, 2011).

Moreover, the individuals' success either at work or in their study can be influenced by the ability to manage their finance (Lusardi \& Mitchell, 2014). Individuals with a financial problem may lose debt due to payback inability, inadequate retirement plan and with more likely low social security. Additionally, a wise financial behaviour was argued to be an essential component in defining and improving one's subjective and objective financial well-being (Garman \& Forgue, 2006; Joo, 2008). For example, well-being in terms of income or assets and financial satisfaction.

The above discussion suggests the following hypotheses:

H3: There is a positive association between financial literacy and financial behaviour.

H5: There is a positive association between financial planning and financial well-being.

H7: Financial behaviour mediates the association between financial literacy and financial well-being. 


\subsubsection{Financial Well-being}

Previous studies provide some evidence on the importance of financial literacy on the individuals' financial well-being (Boddy et al., 2015; Taft et al., 2013; Van Rooij et al., 2011; Lusardi \& Mitchell, 2007; Joo \& Grable, 2004). According to Joo \& Grable (2004), financial literacy can strengthen financial behaviours which indirectly increase the financial well-being. Financially literate persons have the ability to utilise knowledge. They are most likely able to make wise judgments and well-informed savings decisions to avoid any financial affairs (Lusardi \& Mitchell, 2007), thus, leading to greater financial well-being (Taft et al., 2013). In relation to investment, they are able to reduce the risks in finance by diversifying the investment (Van Rooij et al., 2011). Further, some studies discussed on credit instruments in which low-literacy individuals tend to have a poor loan strategy as they are more likely to borrow loan with high interest rates (Lusardi \& Tufano, 2015; Agarwal et al., 2009). The financial literacy is significant to maintain or achieve financial well-being for retirement. Financially literate individuals will trade-off some of their wishes to achieve this objective (Boddy et al., 2015).

Based on the review of the literature, the present study addresses the research questions as follows:

1. What are the antecedents of financial literacy among members of the RMP?

2. Do gender, marital status, age, human capital, income level, financial socialisation, financial stress and motivation influence the financial literacy of the RMP personnel?

3. What are the effects of financial literacy on financial planning and financial behaviour among the RMP personnel?

4. Do financial planning and financial behaviour affect the relationship between financial literacy and financial well-being?

5. Does financial literacy influence financial planning and financial behaviour?

Figure 1 shows the conceptual framework that incorporates the aforesaid theories and variables.

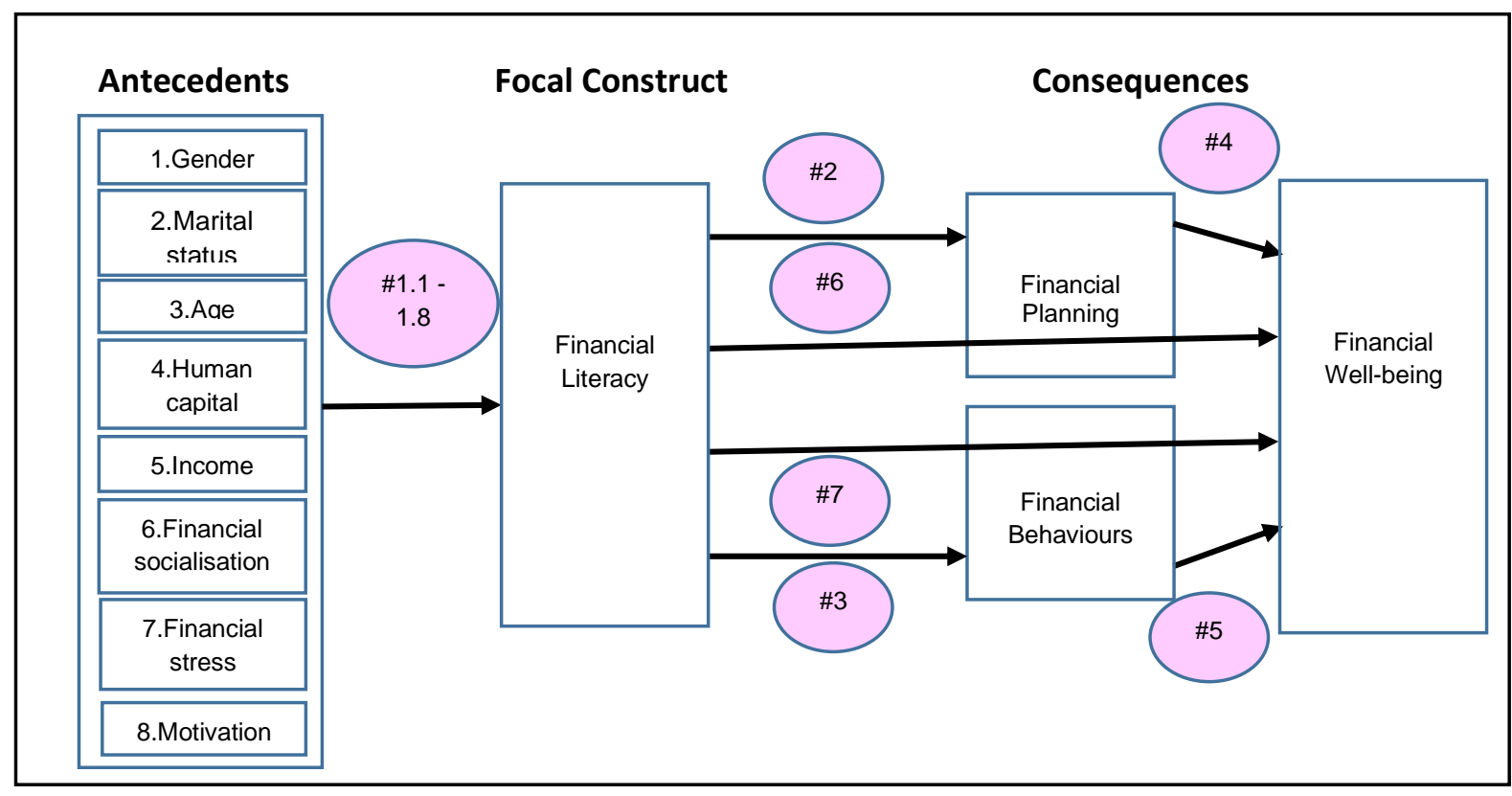

Figure 1. A Conceptual Model of Antecedents and Consequences of Financial Literacy

\section{Methodology of research}

This research is a positivist research in the form of personally administered questionnaire surveys. The measurements of variables in the questionnaire were taken from previous literature. The respondents in the survey are the Royal Malaysia Police personnel. The study used a convenience random sampling technique for data collection as it is convenient, quick and less expensive. The field works were conducted in the Northern region of Peninsular Malaysia. The study received 400 usable responses, giving a response rate of 82 percent. The number of samples achieves the minimum number of sample size for generalisation. 
In terms of analysis, a pilot test had been undertaken prior to the main survey to ensure no issues of reliability and to clarify the questionnaire. No data had been excluded from the data screening with regard to the data from the main survey. The researcher also screened the data to identify the likely problems from the ordinal and ratio variables by using scatter diagrams. The correlation matrix was used to support the interpretation. Results have shown no issue of multicollinearity since the correlation coefficients are less than 0.7. The study then proceeds with univariate analysis, bivariate analysis and multivariate analysis (i.e. Logistic Regression analysis and Multiple Regression analysis). A logistic regression analysis was used because dependent variables (financial literacy) were measured using dichotomous categorical variable; $0=$ wrong and $1=$ correct and mixed (i.e. continuous and categorical) independent variables (Field, 2009). Financial literacy is measured by a percentage of correct answers in knowledge tests. The study calculated an index of financial literacy based on the total number of correct answers. Cronbach's alpha for this composite measure showed an internal consistency of 0.76 . Table 1 presents the questions in the basic literacy which was adopted from Van Rooij $(2011$, p.6). Further, a multiple regression analysis was used to test the focal construct and variables in the consequences (i.e. financial planning, financial behaviour and financial well-being).

Table 1. Themes and Questions of Financial Literacy

\begin{tabular}{|c|c|}
\hline Themes & Questions \\
\hline Numeracy & $\begin{array}{l}\text { "Suppose you had RM100 in a savings account and the interest rate was } 2 \% \text { per year. After } 5 \\
\text { years, how much do you think you would have in the account if you left the money to grow?" - } \\
\text { Van Rooij (2011) }\end{array}$ \\
\hline $\begin{array}{l}\text { Interest } \\
\text { compounding }\end{array}$ & $\begin{array}{l}\text { "Suppose you had RM100 in a savings account and the interest rate is } 20 \% \text { per year and you } \\
\text { never withdraw money or interest payments. After } 5 \text { years, how much would you have on this } \\
\text { account in total?" - Van Rooij (2011) }\end{array}$ \\
\hline Inflation & $\begin{array}{l}\text { "Imagine that the interest rate on your savings account was } 1 \% \text { per year and inflation was } 2 \% \\
\text { per year. After } 1 \text { year, how much would you be able to buy with the money in this account?"- } \\
\text { Van Rooij (2011) }\end{array}$ \\
\hline $\begin{array}{l}\text { Time value of } \\
\text { money }\end{array}$ & $\begin{array}{l}\text { "Assume a friend inherits RM10,000 today and his sibling inherits RM10,000 } 3 \text { years from now. } \\
\text { Who is richer because of the inheritance?"- Van Rooij (2011) }\end{array}$ \\
\hline Money illusion & $\begin{array}{l}\text { "Suppose that in the year 2010, your income has doubled and the prices of all goods have } \\
\text { doubled too. In 2010, how much will you be able to buy with your income?"- Van Rooij (2011) }\end{array}$ \\
\hline
\end{tabular}

\subsection{Description of the variables}

The following table shows a description of the variables for this study together with the expected sign and hypothesis tested. 
Table 2. Description of variables

\begin{tabular}{|c|c|c|c|}
\hline Label & Descriptions & $\begin{array}{l}\text { Expected } \\
\text { sign }\end{array}$ & $\begin{array}{l}\text { Hypothesis } \\
\text { tested }\end{array}$ \\
\hline FinLit & $\begin{array}{l}\text { Whether the person answered the questions correctly or not ( } 1=\text { Correct, } \\
0=\text { Wrong) }\end{array}$ & \multicolumn{2}{|c|}{ Dependent variable } \\
\hline \multicolumn{4}{|c|}{ Antecedents of Financial Literacy } \\
\hline GENDER & Whether male or female (1=Male; $0=$ Female) & $+v e$ & H1.1 \\
\hline MARITAL & $\begin{array}{l}\text { Marital status is a dummy variable }- \text { whether the person is married or } \\
\text { other status ( } 1=\text { Married; } 0=\text { Not married) }\end{array}$ & +ve & $\mathrm{H} 1.2$ \\
\hline AGE & $\begin{array}{l}\text { Current age of the respondent }- \text { it is a dummy variable }(1=25-35 \text { years old; } \\
0=\text { Others) }\end{array}$ & +ve & $\mathrm{H} 1.3$ \\
\hline EDU & $\begin{array}{l}\text { Human capital measures the educational level of the respondent. It is a } \\
\text { dummy variable }(1=\text { If the respondent has a degree or received training in } \\
\text { business/management subjects or holds a professional qualification; } 0=\text { If } \\
\text { not) }\end{array}$ & +ve & $\mathrm{H} 1.4$ \\
\hline INCOME & $\begin{array}{l}\text { Income level is a dummy variable. It is measured by looking at the current } \\
\text { rank ( } 1=\text { Assistant Superintendent of Police- ASP and above; } 0=0 \text { thers }\end{array}$ & +ve & H1.5 \\
\hline FinSoc & Level of agreement ( $1=$ Completely disagree; $0=$ Completely agree) & $+\mathrm{ve}$ & H1.6 \\
\hline FinStress & Level of agreement ( $1=$ Completely disagree; $0=$ Completely agree) & +ve & $\mathrm{H} 1.7$ \\
\hline MOTIVATN & Level of agreement ( $1=$ Completely disagree; $0=$ Completely agree) & +ve & H1.8 \\
\hline \multicolumn{4}{|c|}{ Consequences of Financial Literacy } \\
\hline FinPlan & Extent of frequency ( $1=$ Never; $0=$ =Always) & +ve & $\mathrm{H} 2$ \\
\hline FinBehave & Extent of frequency ( $1=$ Never; $0=$ =Always) & $+\mathrm{ve}$ & $\mathrm{H} 3$ \\
\hline FinWell & Extent of frequency (1=Never; $0=$ =Always) & $+\mathrm{ve}$ & $\mathrm{H} 4 \& \mathrm{H} 5$ \\
\hline
\end{tabular}

\section{Results and discussions}

\subsection{Univariate and bivariate analysis}

The key results of responses to the questions are as follows. The majority of the police personnel (57\%) are financially illiterate. Out of $57 \%$, the majority has answered correctly for questions on numeracy and money illusion (approximately $78 \%$ and $73 \%$, respectively) and less than half of them can answer correctly for questions on interest compounding (45\%), inflation (42\%) and time value of money (48\%).

A non-parametric Mann-Whitney $U$ test of difference was conducted for not normally distributed independent variables (FinSoc, MOTIVATN, FinStress) against the dependent variable (FinLit). Table 3 presents a low level of probability statistic. All predictors are included in the logistic regression as it portrays a significant difference between the mean ranks of the two sub-samples in the FinLit.

Table 3. Mann-Whitney U Tests on non-parametric predictors

\begin{tabular}{|c|c|c|c|c|c|}
\hline Label & \multicolumn{2}{|c|}{ Financial Literacy } & Mann-Whitney U & Z & P \\
\hline & Correct & Wrong & & & \\
\hline FinSoc & 241 & 159 & 12186.5 & -2.694 & .000 \\
\hline MOTIVATN & 238 & 162 & 9347.0 & -3.478 & .000 \\
\hline FinStress & 237 & 163 & 7065.5 & -6.144 & .000 \\
\hline
\end{tabular}

On the other hand, Table 4 presents a correlation matrix for continuous variables. The correlation coefficients are less than 0.7 which indicates that there is no "overlap in the predictive power of explanatory variables" (Kervin, 1992, p.608).

Table 4. Correlation matrix of continuous independent variables

\begin{tabular}{|l|c|c|c|}
\hline & 1 & 2 & 3 \\
\hline FinSoc & FinSoc & MOTIVATN & FinStress \\
\hline MOTIVATN & 1 & & \\
\hline FinStress & $.61\left(^{* *}\right)$ & 1 & \\
\hline
\end{tabular}

Notes: $\mathrm{N}=400-*$ Correlation is significant at the 0.01 level (2-tailed) 
The remaining independent variables were analysed using a Chi-square test as they are categorical variables (i.e. GENDER, MARITAL, AGE, EDU and INCOME). The test measured the relationship between all predictors and FinLit. All variables are included in the model as the results showed a strong relationship in each case.

\subsection{Multivariate analysis}

Firstly, this study performed a factor analysis on the binary variables of FinLit using the iterated principal factor method. Factor loadings were calculated and the factor scores were obtained using the Bartlett method. Secondly, the study performed a Logistic regression analysis to address research questions 1 and 2. The analysis tested the hypotheses 1.1 to 1.8 (Figure 1). The analysis comprises of Model 1 and Model 2. Model 1 served as the base model for the analysis. Model 1 comprised of the following variables (i.e. GENDER, MARITAL, AGE, EDU, INCOME). Next, all significant variables in Model 1 were added together with continuous independent variables (i.e. FinSoc, FinStress and MOTIVATN) in Model 2. This study used a forward stepwise method to make sure all candidate variables were fitted to the model.

Table 5. Logistic Regression Model for Financial Literacy

\begin{tabular}{|c|c|c|c|c|c|}
\hline Variable & Expected sign & $B$ & Wald & $\boldsymbol{P}$ & Expected (B) \\
\hline GENDER & + & -.067 & .095 & .715 & 3.121 \\
\hline MARITAL & + & 1.151 & 6.438 & .011 & 3.162 \\
\hline AGE & + & -.328 & .412 & .523 & .144 \\
\hline EDU & + & 1.416 & 12.271 & .000 & 4.122 \\
\hline INCOME & + & .447 & 12.260 & .003 & 2.667 \\
\hline FinSoc & + & .974 & 16.030 & .000 & 2.648 \\
\hline FinStress & + & .421 & 17.084 & .000 & 3.173 \\
\hline MOTIVATN & + & .579 & 16.761 & .010 & 2.871 \\
\hline Constant value & & -.463 & & & \\
\hline Chi-square & & & $94.450 *$ & & \\
\hline-2 Log likelihood & & & 235.250 & & \\
\hline Hosmer\&Lemeshow $R^{2}$ & & & 0.819 & & \\
\hline
\end{tabular}

With regard to the nominal independent variables, this study failed to reject the null hypotheses for GENDER (H1.1) and AGE (H1.3) ( $p \geq 0.05)$. The results for MARITAL, EDU and INCOME are significant ( $p \leq$ 0.05). These factors had a positive effect on the odds of financial literacy, which support H1.2, H1.4 and H1.5 (reject the null hypotheses). The results show that, for a one-point increase in MARITAL, EDU and INCOME, the individuals would be triple, quadruple and twice financially literate, respectively. All continuous independent variables, i.e. FinSoc, FinStress and MOTIVATN are found to be positively significant in the model $(p \leq 0.05)$. A one-point increase in these three scores will increase the odds by 2.648, 3.179 and 2.871 times.

The Wald statistics in Table 5 indicates that FinStress is the most influential factor of financial literacy, followed by MOTIVATN, FinSoc, EDU, INCOME, and MARITAL. As for the goodness of fit for the model, this study looked at the -2Log likelihood (-2LI) of the model and the significant value of Hosmer \& Lemeshow R Squared. -2LI of the model is $329.70^{1}$, which is lesser than in the previous model (with only the constant). The value shows that the $-2 \mathrm{LI}$ model predicts an accurate outcome variable. Likewise, Hosmer \& Lemeshow R Squared show adequate goodness of fit for the model as the value is not significant. The model explains $81.9 \%$ of the variance. Additionally, the $p$-value of Chi-square is less than 0.001 ; which indicates that there are significant relationships between the predictors and financial literacy. 
Thirdly, the study tested hypotheses 2 and 3 . Table 6 indicates that the model is significant $(p-$ value $=0.046$ ) and the standardized coefficient beta shows a positive association between FinLit and FinPlan. Similarly, Table 7 exhibits a significant $(p$-value $=0.025$ ) and a positive association between FinLit and FinBehave. Therefore, the study accepted the $\mathrm{H} 2$ and $\mathrm{H} 3$.

Table 6. Results of T-Statistics (Financial Literacy and Financial Planning)

\begin{tabular}{|c|c|c|c|c|c|}
\hline & \multicolumn{2}{|c|}{ Unstandardized coefficients } & Standardized coefficients & t & Significant \\
\hline & B & Standard error & Beta & B & Standard error \\
\hline Constant & 4.519 & 0.320 & & 12.661 & 0.000 \\
\hline FinPlan & 0.299 & 0.109 & 0.300 & 2.876 & 0.046 \\
\hline
\end{tabular}

Table 7. Results of T-Statistics (Financial Literacy and Financial Behaviour)

\begin{tabular}{|c|c|c|c|c|c|}
\hline & \multicolumn{2}{|c|}{ Unstandardized coefficients } & Standardized coefficients & t & Significant \\
\hline & B & Standard error & Beta & B & \\
\hline Constant & 2.998 & 0.395 & & 7.289 & 0.000 \\
\hline FinBehave & 0.273 & 0.104 & 0.312 & 2.902 & 0.025 \\
\hline
\end{tabular}

Finally, the study performed a multiple regression analysis to address the research questions 3,4 and 5. The analysis tested the hypotheses 4 to 7 (Figure 1).

Table 8. Results of multiple regression analyses

\begin{tabular}{|l|c|c|c|c|}
\hline \multirow{2}{*}{\multicolumn{1}{|c|}{ Independent variables }} & \multicolumn{4}{c|}{ Financial Well-being } \\
\cline { 2 - 5 } FinPlan & 1 & 2 & 3 & 4 \\
& 0.0001 & - & 0.0005 & 0.102 \\
$(0.0002)$ & $0.0003)$ & $(0.0003)$ \\
\hline \multirow{2}{*}{ FinBehave } & 0.701 & - & - & 0.700 \\
& $(0.103)$ & $-0.106)$ \\
\hline Two-way Interactions & 0.054 & - & $0.364^{*}$ & $0.331^{*}$ \\
\hline \multirow{2}{*}{ FinLit by FinPlan } & $(0.122)$ & $0.099)$ & $(0.111)$ \\
\hline \multirow{2}{*}{ FinLit by FinBehave } & 0.043 & 0.147 & -0.322 & $-0.036^{*}$ \\
& $(0.081)$ & $(0.063)$ & $(0.044)$ & $(0.031)$ \\
\hline Adjusted R-Square & 0.63 & 0.52 & 0.69 & 0.68 \\
\hline F-Statistics & $19.214^{*}$ & $32.375^{*}$ & $15.885^{*}$ & $21.225^{*}$ \\
\hline
\end{tabular}

The above table shows the model for financial well-being. It is moderately fit. The F-statistics are statistically significant $(p \leq 0.0001)$. The results show that the explanatory powers of the overall models are adequate as the Adjusted R-squares range from 0.52 to 0.69 . Models 1 and 2 are the direct effect models controlling the effect of FinLit; while the latter models ( 3 and 4 ) account for both direct and indirect effects of the financial literacy on financial well-being.

Looking first at the direct effect of FinPlan and FinBehave with the FinWell, there is no evidence to reject the null hypotheses for $\mathrm{H} 4$ and $\mathrm{H} 5$ as the p-values are more than 0.05 . On the other hand, results show a significant association for the two-way interactions (i.e. when the effect of the mediator is included); which support $\mathrm{H} 6$ and $\mathrm{H} 7$.

\subsection{Discussions}

A number of significant findings have been derived from this study. The findings gave evidence to follow the theory of planned behaviour, theory of mental accounting and stress coping theory. There is no evidence to support the life-cycle theory as the results showed no association between AGE and FinLit (H1.3). The level of financial literacy among the respondents depends on their intentions to behave and they will act in accordance with their beliefs and motivation. This is in line with the argument of Ajzen \& Fishbein (2005) who argued that human actions depend on behavioural belief, normative belief, and control belief. In addition, the findings follow stress-coping theory in relation to psychological stress. The majority of the police personnel were found to encounter situations requiring potential financial 
expenditures, and they are appraising the effects the expenditures might have on their personal well-being, both immediately and for a longer-term.

\section{Implications and contributions of the study}

Findings of the research help to promote a complete concept of financial literacy by incorporating financial stress, financial behaviours, financial planning and financial well-being into the model of antecedents and consequences of financial literacy. This study presents a model of financial literacy from the viewpoint of members of the police force. Essentially, the research is the pioneer study in Malaysia which seeks to investigate financial issues among the police personnel, especially on the antecedents and consequences of financial literacy. Additionally, findings of this research are hoped to add to the literature on personal finance and to assist in generating an understanding and consciousness regarding sound financial planning and management for the general public and specifically, for members of the RMP. The police personnel should be fully aware that a low level of financial literacy would affect their financial behaviours and hinder them from making good financial planning and decisions. This, in turn, will have an adverse impact on the personnel's financial well-being.

An appreciation on the importance of good financial behaviours and financial resiliency among members of the RMP can help the policy-makers in devising appropriate policies for the benefits of the RMP and its personnel. In specific, the findings of this research should give the Ministry of Home Affairs, Malaysia, a clearer picture and better insights into the genuine problems of financial literacy and financial predicaments affecting the RMP personnel. The existence of contributing factors like the financial stress will enlighten the public on the efficacy of the government's efforts to assist the police personnel in achieving peace of mind and better concentration while performing their role in maintaining law and order and to protect the public.

Moreover, the findings should assist in realising the government's aspiration as contained in the National Strategy for Financial Literacy 2019-2023. The findings should also help in improving the level of financial literacy among the Malaysians, besides promoting responsible behaviours and rational attitudes to guarantee the overall well-being of the people, particularly from financial perspectives.

\section{Conclusions and recommendations}

This issue of financial literacy among members of the RMP is a burning issue which will ultimately affect the effectiveness, professionalism, and impartiality of the police institution. Findings, impacts and novel of this study must be considered with some limitations. The model as presented in the study is a simple one which is derived from several models. Although many predictors influencing financial literacy have been researched, other factors may have been used or even have been more useful. Another thing to consider is that, although after completing the process of reviewing the main assumptions as well as inserting a number of subjective financing decisions' frameworks to the specifications of the models, the models still need to be improved and refined so as to enable them to represent scenarios in different places. The conclusions of the study are dependent on personal behaviours at a certain time, and any development after July 2019 is disregarded.

Nevertheless, the limitations do not lessen the significance of findings, but they provide a basis for future research to validate and develop the theoretical framework as shown in this study. Future study is necessary to relate the financial literacy of the Malaysian police personnel with those in other developed and developing countries, and to examine the differences to improve our knowledge on the financing needs. It would also be beneficial to make a comparative study on the financial literacy of the police and military forces since the two services have their unique characteristics resulting from their legal status, authority and powers, and the level of their closeness and connection with the general public. 


\section{References}

1. Adam, A. M., Frimpong, S., \& Boadu, M. O. (2017). Financial literacy and financial planning: Implication for financial well-being of retirees. Business and Economic Horizons, 13(2), 224-236.

2. Agarwal, S., Driscoll, J. C., Gabaix, X., \& Laibson, D. (2009). The age of reason: Financial decisions over the life cycle and implications for regulation. Brookings Papers on Economic Activity, 2009(2), 51-117.

3. Ajzen, I., \& Fishbein, M. (2005). The influence of attitudes on behavior. The handbook of attitudes, 173(221), 31.

4. Allgood, S., \& Walstad, W. B. (2016). The effects of perceived and actual financial literacy on financial behaviors. Economic inquiry, 54(1), 675-697.

5. Almenberg, J., \& Dreber, A. (2015). Gender, stock market participation and financial literacy. Economics Letters, 137, 140-142.

6. Atkinson, A., \& Messy, F. A. (2012). Measuring financial literacy: Results of the OECD. OECD Publishing.

7. Bachmann, G. R., John, D. R., \& Rao, A. R. (1993). Children's susceptibility to peer group purchase influence: an exploratory investigation. Advances in Consumer Research, 20, 463-468.

8. Bayer, P. J., Bernheim, B. D., \& Scholz, J. K. (1996). Effects of financial education in the workplace. Stanford University, Working Paper no. 96- 011.

9. Bernardo, A. B., \& Fernando-Resurreccion, K. (2018). Financial stress and well-being of Filipino students: The moderating role of external locus-of-hope. Philippine Journal of Psychology, 51(1), 33-61.

10.Bernheim, B. D., Garrett, D. M., \& Maki, D. M. (2001). Education and saving: The long-term effects of high school financial curriculum mandates. Journal of public Economics, 80(3), 435-465.

11.Bhushan, P., \& Medury, Y. (2013). Financial literacy and its determinants. International Journal of Engineering, Business and Enterprise Applications, 4(2), 155-160.

12.Boddy, D., Dokko, J., Hershbein, B., \& Kearney, M. S. (2015). Ten Economic Facts about Financial Well-Being in Retirement. Brookings Institution.

13.Bongini, P., \& Zia, B. (2018). Introduction: The financial literacy collective. Economic Notes: Review of Banking, Finance and Monetary Economics, 47(2-3), 235-244.

14.Bongini, P., Trivellato, P., \& Zenga, M. (2015). Business students and financial literacy: When will the gender gap fade away? Journal of Financial Management, Markets and Institutions, 3(1), 13-30.

15.Boon, T. H., Yee, H. S., \& Ting, H. W. (2011). Financial literacy and personal financial planning in Klang Valley, Malaysia. International Journal of Economics and Management, 5(1), 149-168.

16.Bottazzi, L., \& Lusardi, A. (2016). Gender differences in financial literacy: Evidence from PISA data in Italy1. Global Financial Literacy Excellence Center (GFLEC) Working Paper, Washington DC.

17.Brian, K. (2015). OECD Insights Income Inequality. The Gap between Rich and Poor: The Gap between Rich and Poor. OECD Publishing.

18.Brown, M., \& Graf, R. (2013). Financial literacy and retirement planning in Switzerland. Numeracy, 6(2), 6.

19.Butt, A., Donald, M. S., Foster, F. D., Thorp, S., \& Warren, G. J. (2017). Design of mysuper default funds: influences and outcomes. Accounting \& Finance, 57, 47-85.

20.Calamato, M. (2010). Learning financial literacy in the family (Master's thesis). Retrieved from ProQuest Dissertations and Theses database. (AAT 1488108)

21.Calcagno, R., \& Monticone, C. (2015). Financial literacy and the demand for financial advice. Journal of Banking \& Finance, 50, 363-380.

22.Chaffin, C. R. (2013). The financial planning competency handbook. Canada: John Wiley\& Sons, Inc.

23.Cheah, E., Devadason, R., Sito, A., \& Wong, B. C. (1998) Financial Freedom-Your Guide to Lifetime Financial Planning, KL Mutual Fund Berhad, Kuala Lumpur.

24.Cheah, K. K., Foster, F. D., Heaney, R., Higgins, T., Oliver, B., O'Neill, T., \& Russell, R. (2015). Discussions on long-term financial choice. Australian Journal of Management, 40, 414-434.

25.Cheema, A., \& Soman, D. (2006). Malleable mental accounting: The effect of flexibility on the justification of attractive spending and consumption decisions. Journal of Consumer Psychology, 16(1), 3344. 
26.Chen, H., \& Volpe, R. P. (2002). Gender differences in personal financial literacy among college students. Financial Services Review, 11(3), 289-308.

27.Clarke, M. C., Heaton, M. B., Israelsen, C. L., \& Eggett, D. L. (2005). The acquisition of family financial roles and responsibilities. Family and Consumer Sciences Research Journal, 33(4), 321-340.

28.Commonwealth Bank Foundation (CBF). (2004). Improving Financial Literacy in Australia: Benefits for the Individual and the Nation, Research

29.Dam, L. B., \& Hotwani, M. (2018). Financial Literacy: Conceptual Framework and Scale Development. SAMVAD, 15, 61-69.

30.De Clercq, B., \& Venter, J. M. P. (2009). Factors influencing a prospective chartered accountant's level of financial literacy: an exploratory study. Meditari Accountancy Research, 17(2), 47-60.

31.Delafrooz, N., Paim, L., Sabri, M. F., \& Masud, J. (2010). Effects of financial wellness on the relationship between financial problem and workplace productivity. World Applied Sciences Journal, 10(8), 871-878.

32.Dew, J. P. (2016). Revisiting financial issues and marriage. In Handbook of consumer finance research (pp. 281-290). Springer, Cham.

33.Duflo, E., \& Saez, E. (2003). The role of information and social interactions in retirement plan decisions: Evidence from a randomized experiment. The Quarterly journal of economics, 118(3), 815-842.

34.Edwards, R., Allen, M. W., \& Hayhoe, C. R. (2007). Financial attitudes and family communication about students' finances: The role of sex differences. Communication Reports, 20(2), 90-100.

35.Elliehausen, G., Lundquist, E. C., \& Staten, M. E. (2003). The impact of credit counseling on subsequent borrower credit usage and payment behavior. Credit Research Center, Georgetown University.

36.Falahati, L., \& Sabri, M. F. (2015). An exploratory study of personal financial wellbeing determinants: Examining the moderating effect of gender. Asian Social Science, 11(4), p33.

37.Fernandes, D., Lynch Jr, J. G., \& Netemeyer, R. G. (2014). Financial literacy, financial education, and downstream financial behaviors. Management Science, 60(8), 1861-1883.

38.Field, A. (2009). Discovering Statistics Using SPSS. 3rd Edition. Sage.

39.Fishbein, M., \& Ajzen, I. (1975). Belief, attitude, intention and behavior: An introduction to theory and research. Addison-Wesley, Reading, Mass.

40.Fonseca, R., Mullen, K. J., Zamarro, G., \& Zissimopoulos, J. (2012). What explains the gender gap in financial literacy? The role of household decision making. Journal of Consumer Affairs, 46(1), 90-106.

41.Furnham, A., Von Stumm, S., \& Fenton-O'Creevy, M. (2015). Sex differences in money pathology in the general population. Social Indicators Research, 123(3), 701-711.

42.Garman, E. T., \& Forgue, R. E. (2006). Personal finance. Boston: Houghton Mifflin Company.

43.Garman, E. T., Kim, J., Kratzer, C. Y., Brunson, B. H., \& Joo, S. H. (1999). Workplace financial education improves personal financial wellness. Financial Counseling and Planning, 10(1), 79-88.

44. Hastings, J. S., \& Mitchell, O. S. (2011). How financial literacy and impatience shape retirement wealth and investment behaviors (No. w16740). National Bureau of Economic Research.

45. Herawati, N. T., Candiasa, I. M., Yadnyana, I. K., \& Suharsono, N. (2018). Factors that influence financial behavior among accounting students in Bali. International Journal of Business Administration, 9(3), 30.

46. Hira, T. K., \& Loibl, C. (2005). Understanding the impact of employer-provided financial education on workplace satisfaction. Journal of Consumer Affairs, 39(1), 173-194.

47.Hirad, A., \& Zorn, P. M. (2001). A little knowledge is a good thing: Empirical evidence of the effectiveness of pre-purchase homeownership counseling. Cambridge, MA: Joint Center for Housing Studies of Harvard University.

48.Iregui-Bohórquez, A. M., Melo-Becerra, L. A., Ramírez-Giraldo, M. T., and Tribín-Uribe, A. M. (2018). Determinants of Formal and Informal Saving in Colombia. Financial Decisions of Households and Financial Inclusion: Evidence for Latin America and the Caribbean, p.95.

49.Jappelli, T., Marino, I., and Padula, M. (2019). Pension Uncertainty and Demand for Retirement Saving (No. 526). Centre for Studies in Economics and Finance (CSEF), University of Naples, Italy.

50.Joo, S. (2008). Personal financial wellness. In Handbook of consumer finance research (pp. 21-33). Springer, New York, NY. 
51.Joo, S. H., \& Grable, J. E. (2004). An exploratory framework of the determinants of financial satisfaction. Journal of Family and Economic Issues, 25(1), 25-50.

52.Kalmi, P., \& Ruuskanen, O. P. (2018). Financial literacy and retirement planning in Finland. Journal of Pension Economics \& Finance, 17(3), 335-362.

53.Kast, F., Meier, S., \& Pomeranz, D. (2016, April). Saving more in groups: Field experimental evidence from Chile. (HBS Working Paper No 12-060). Available from: http://www.hbs.edu/faculty/Publication\%20Files/12- $\quad 060 \_8 c 16 f 5 e 7-6 f a 1-48 c c-858 d-b b a 5 f 12 c 28 b a . p d f$. Accessed 25 June 2019.

54.Kervin, J. B. (1992). Methods for Business Research. New York: HarperCollins.

55.Kim, J., \& Chatterjee, S. (2013). Childhood Financial Socialization and Young Adults' Financial Management. Journal of Financial Counseling \& Planning, 24(1).

56.Kindle, P. A. (2010). Student perceptions of financial literacy: Relevance to practice. Journal of Social Service Research, 36(5), 470-481.

57.Klapper, L., Lusardi, A., and Panos, G. A. (2013), Financial literacy and its consequences: Evidence from Russia during the financial crisis. Journal of Banking and Finance, 37, 3904-3923.

58.Klapper, L., Lusardi, A., \& Van Oudheusden, P. (2015). Financial literacy around the world. Standard \& Poor's Ratings Services Global Financial Literacy Survey. Available from: http://media. mhfi.com/documents/2015-Finlit_paper_17_F3_SINGLES. pdf. Accessed 25 June 2019.

59.Lauer, S. R., \& Yodanis, C. (2014). Money management, gender and households. The Wiley Blackwell Companion to the Sociology of Families, 344-360.

60.Lazarus, R. S., \& Folkman, S. (1984). Coping and adaptation. The Handbook of Behavioral Medicine, 282325.

61.Lee, Y.-G., \& Lown, J. M. (2012). Effects of financial education and impulsive buying on saving behavior of Korean college students. International Journal of Human Ecology, 13(1), 159-169.

62.Locke, E. A., \& Latham, G. P. (2004). What should we do about motivation theory? Six recommendations for the twenty-first century. Academy of management review, 29(3), 388-403.

63.Lusardi, A. (2015). Financial literacy skills for the 21st century: Evidence from PISA. Journal of consumer affairs, 49(3), 639-659.

64.Lusardi, A., \& Mitchell, O. S. (2007). Baby boomer retirement security: The roles of planning, financial literacy, and housing wealth. Journal of Monetary Economics, 54(1), 205-224.

65.Lusardi, A., \& Mitchell, O. S. (2011). Financial literacy around the world: an overview. Journal of Pension Economics \& Finance, 10(4), 497-508.

66.Lusardi, A., \& Mitchell, O. S. (2014). The economic importance of financial literacy: Theory and evidence. Journal of Economic Literature, 52(1), 5-44.

67.Lusardi, A., \& Tufano, P. (2015). Debt literacy, financial experiences, and over indebtedness. Journal of Pension Economics \& Finance, 14(4), 332-368.

68.Mahapatra, M. S., Raveendran, J., \& De, A. (2019). Building a model on influence of behavioural and cognitive factors on personal financial planning: A Study among Indian households. Global Business Review, p.0972150919844897.

69.Mahdzan, N. S., Zainudin, R., Sukor, M. E. A., Zainir, F., \& Ahmad, W. M. W. (2019). Determinants of subjective financial well-being across three different household income groups in Malaysia. Social Indicators Research, 1-28.

70.Malaysia Bankruptcy Statistics Report (2018). Available from: http://www.mdi.gov.my/index.php/about-us/resources/statistics/bankruptcy/1390-. Accessed 2 July 2019.

71. Malaysia Financial Planning Council, MFPC (2004) RFP Module 1- Fundamentals of Financial Planning, 3rd ed., MFPC, Kuala Lumpur.

72.Mandell, L., \& Klein, L. S. (2007). Motivation and financial literacy. Financial services review, 16(2), 105.

73. Marks, G. N. (2007), Income poverty, subjective poverty and financial stress, Social Policy Research Paper, 29, FaCSIA, Canberra.

74.Nawi, M. H. (2015). Determinants of capital structure in small and medium sized enterprises in Malaysia (Doctoral dissertation, Brunel University London). 
75.McPherson, A. V. (2012). College Student Life and Financial Stress: An Examination of the Relation Among Perception of Control and Coping Styles on Mental Health Functioning. Available from: https://repository.lib.ncsu.edu/bitstream/handle/1840.16/7493/etd.pdf?sequence=2. Accessed 25 June 2019.

76. Monticone, C. (2010). How much does wealth matter in the acquisition of financial literacy?. Journal of Consumer Affairs, 44(2), 403-422.

77.Mottola, G. R. (2013). In our best interest: Women, financial literacy, and credit card behavior. Numeracy, 6(2), 4.

78.Nano, D., \& Cani, S. (2013). The differences in students' financial literacy based on financial education. Academicus International Scientific Journal, 2013(8), 149-160.

79.National Strategy for Financial Literacy. (2019-2023). Available from: https://www.fenetwork.my/. Accessed 2 August 2019.

80.Noctor, M., Stoney, S., and Stradling, R. (1992). Financial literacy: a discussion of concepts and competences of financial literacy and opportunities for its introduction into young people's learning. Report prepared for the National Westminster Bank, National Foundation for Education Research, London.

81.0'Neill, B., Prawitz, A., Sorhaindo, B., Kim, J., \& Garman, E. T. (2006). Changes in health, negative financial events, and financial distress/financial well-being for debt management program clients. Financial Counseling and Planning, 17(2), 46-63.

82.O'Neill, B., Xiao, J. J., Sorhaindo, B., \& Garman, E. T. (2005). Financial distressed consumers: Their financial practices, financial wellbeing, and health. Financial Counseling and Planning, 16(1), 73-87.

83.OECD (Organisation for Economic Cooperation and Development). (2013). OECD/INFE toolkit to measure financial literacy and financial inclusion: Guidance, core questionnaire and supplementary questions. Available from:

http://www.oecd.org/daf/fin/financialeducation/TrustFund2013_OECD_INFE_toolkit_to_measure_fin_lit _and_fin_incl.pdf. Accessed 14 March 2019.

84.Pahl, J. (2005). Individualisation in couple finances: who pays for the children?. Social Policy and Society, 4(4), 381-391.

85.Peng, T. M., Bartholomew, S., Fox, J. J., \& Cravener, G. (2007). The impact of personal financial education delivered in high school and college courses. Journal of Family and Economic Issues, 28, 265-284.

86.Penrose, E. T. (1952). Biological analogies in the theory of the firm. The American Economic Review, 42(5), 804-819.

87.Rootman, C., \& Antoni, X. (2018). Demographic factors affecting the financial literacy of black consumers: critical research in South Africa. In The 2018 Annual Conference of the Emerging Markets Conference Board (p.215-230). Wits Business School.

88.Samuelson, P. (1967). Economics. New York: McGraw-Hill Book Co.

89.Schor, J. B. (2004). Born to buy: The commercialized child and the new consumer culture. New York: Scribner.

90.Schuchardt, J., Hanna, S. D., Hira, T. K., Lyons, A. C., Palmer, L., \& Xiao, J. J. (2009). Financial literacy and education research priorities. Journal of Financial Counseling and Planning, 20(1), 84-95.

91.Servon, L. J., \& Kaestner, R. (2008). Consumer financial literacy and the impact of online banking on the financial behavior of lower-income bank customers. Journal of Consumer Affairs, 42(2), 271-305.

92.Smith, N., \& Weatherburn, D. (2013). Personal stress, financial stress, social support and women's experiences of physical violence: A longitudinal analysis. BOCSAR NSW Crime and Justice Bulletins, 20.

93.Sohn, S. H., Joo, S. H., Grable, J. E., Lee, S., \& Kim, M. (2012). Adolescents' financial literacy: The role of financial socialization agents, financial experiences, and money attitudes in shaping financial literacy among South Korean youth. Journal of Adolescence, 35(4), 969-980.

94.Stanca, L. (2012). Suffer the little children: Measuring the effects of parenthood on well-being worldwide. Journal of Economic Behavior \& Organization, 81(3), 742-750.

95.Stoughton, N. M., Wu, Y., \& Zechner, J. (2011). Intermediated investment management. The Journal of Finance, 66(3), 947-980. 
96.Struwig, J., Roberts, B., \& Gordon, S. (2016). Financial Literacy in South Africa: Results from the 2015 South African Social Attitudes Survey round. Report prepared by the Human Sciences Research Council (HSRC) on behalf of the Financial Services Board (FSB). Pretoria: Financial Services Board.

97.Taft, M. K., Hosein, Z. Z., Mehrizi, S. M. T., \& Roshan, A. (2013). The relation between financial literacy. Financial wellbeing and financial concerns. International Journal of Business and Management, 8(11), 63-75.

98. Thaler, R. H. (2013). Financial literacy, beyond the classroom. The New York Times.

99.Thaler, R. H. 'Mental accounting and consumer choice', Marketing Science, 4 (1985), 199-214.

100. Thaler, R. H. (1999). Mental accounting matters. Journal of Behavioral decision making, 12(3), pp.183-206.

101. Thapa, B. S. (2015). Financial literacy in Nepal: A survey analysis from college students. NRB Economic Review, 27(1), 49-74.

102. The Official Portal of Royal Malaysia Police. Available from: http://rmp.gov.my/. Accessed 17 April 2019.

103. Van Rooij, M., Lusardi, A., \& Alessie, R. (2011). Financial literacy and stock market participation. Journal of Financial Economics, 101(2), 449-472.

104. Van Rooij, M. C. J., Lusardi, A., \& Alessie, R. (2012). Financial literacy, retirement planning and household wealth. Economic Journal, 122, 449-478.

105. Vitt, L. A., Anderson, C., Kent, J., Lyter, D. M., Siegenthaler, J. K., \& Ward, J. (2000). Personal finance and the rush to competence: Personal financial literacy in the U.S. The Fannie Mae Foundation.

106. Von Gaudecker, H. M. (2015). How does household portfolio diversification vary with financial literacy and financial advice? Journal of Finance, 70, 489-507.

107. Vroom, V. H. (1964). Work and Motivation. New York: John Wiley \& Sons.

108. Wagland, S. P., \& Taylor, S. (2009). When it comes to financial literacy, is gender really an issue? Australasian Accounting, Business and Finance Journal, 3(1), 3.

109. Wagner, J. (2015). An analysis of the effects of financial education on financial literacy and financial behaviors. Dissertations, Theses, and Student Research from the College of Business. 50.

110. Wong, G., Zane, N., Saw, A., \& Chan, A. K. K. (2013). Examining gender differences for gambling engagement and gambling problems among emerging adults. Journal of Gambling Studies, 29(2), 171-189.

111. Xiao, J. J., \& Porto, N. (2016). Which financial advice topics are positively associated with financial satisfaction? Journal of Financial Planning, 29(7), 52-60

112. Xiao, J. J., Sorhaindo, B., \& Garman, E. T. (2006). Financial behaviours of consumers in credit counselling. International Journal of Consumer Studies, 30(2), 108-121.

113. Xue, R., Gepp, A., O'Neill, T. J., Stern, S., \& Vanstone, B. J. (2019). Financial literacy amongst elderly Australians. Accounting \& Finance, 59, 887-918.

114. Yoshino, N., Morgan, P., \& Wignaraja, G. (2015). Financial education in Asia: Assessment and recommendations. ADBI Working Paper, No. 534, Asian Development Bank Institute (ADBI), Tokyo.

115. Zhang, C. Y., \& Sussman, A. B. (2017). The role of mental accounting in household spending and investing decisions. Client Psychology. New York: Wiley.

116. Zulaihati, S., Susanti, S., \& Widyastuti, U. (2020). Teachers' financial literacy: Does it impact on financial behaviour? Management Science Letters, 10(3), 653-658. 